\title{
Model of Transformation of Cadastral Maps of Former Austrian Annexation with Additional Conditions on Transformation Parameters
}

\section{Introduction}

Although cadastral maps, of former Austrian annexation comes from the second part of XIX century very often, yet they are still source of data in many cadastral units located in southern-eastern part of Poland. These maps are used very often as contemporary cadastral maps in unchanged scale 1:2880 or as rescaled maps to metric scale 1:2000. Possibility of application of former Austrian cadastral maps for various surveying-legal works has been presented, among others in [5] or in [4].

It is worth mentioning that even in case when there is modernized cadastre in specific cadastral unit according to [6], yet such cadastral maps are still used as basic source for analysis during delimitations or other works dealing with determination of parcel boundaries. Unfortunately, there is very often a lack of control points, tying reference system of cadastral maps with current reference system. For transformation of such maps, using fixed field points like "three-balks", corners of buildings [3] or cadastral control points [8]. According to mentioned authors' opinion, a big problem each time was to capture points which could be regarded as control points during transformation of former Austrian cadastral maps. As control points, as it has already been mentioned, being drawn on former cadastral maps and possible to identify in the field. However, because passage of years, to search out such points can be very difficult. Yet, in many cases it is possible to identify parcel boundary being on former cadastral map with those, existing in the field, now. One should absolutely add, that ends of boundary lines, as a results of changes of field development (broadening of road, changes of river bed, etc.), are difficult to identify, sometimes. Such example is shown on Figure 1, where contemporary cadastral situation is drawn by red colour, while former cadastral situation - cadastral map, is drawn by gray colour.

* AGH University of Science and Technology, Faculty of Mining Surveying and Environmental Engineering, Krakow, Poland 


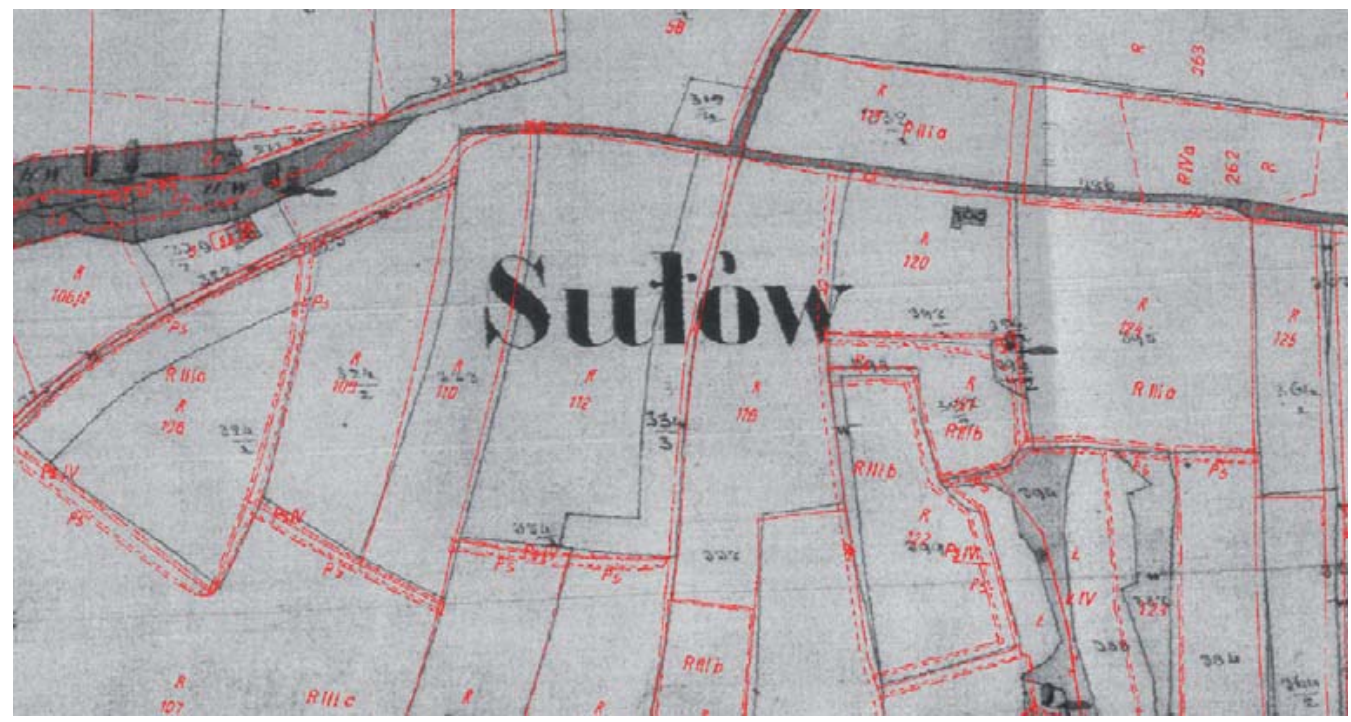

Fig. 1. Change of location of boundary points with keeping direction of boundary

In case of little number of control points or their incorrect location, it is possible to put additional conditions on transformation coefficient. Such conditions put into transformation process, will cause consistency of location boundaries being in the field with boundaries existing on former cadastral map, previously calibrated. These conditions can also be added to long boundary lines, which ends can be treated as control points. Such application of discussed conditions could improve reliability of boundary course, determined on the basis of cadastral map.

Solution of such model would increase accuracy of transformation of mentioned, cadastral maps.

\section{Definition of Conditional Equations}

Assume, that desirable transformation, in case of former cadastral maps, is affine transformation. This transformation, after [7] is defined by formulas:

$$
\begin{aligned}
& X_{w}=a X_{p}+b Y_{p}+c \\
& Y_{w}=d X_{p}+e Y_{p}+f
\end{aligned}
$$

where:

$X_{w}, Y_{w}-$ coordinates of points in secondary system,

$X_{p^{\prime}} Y_{p}-$ coordinates of points in primary system,

$a, b, c, d, e, f-$ coefficients of transformation. 
Determination of conditional equation is based upon equation of a line goes through two points, whereby coordinates of these points are determined in secondary (field) system. Equation of line goes through point A of coordinates $\left(X_{w_{A}}, Y_{w_{A}}\right)$ and point B of coordinates $\left(X_{w_{B}}, Y_{w_{B}}\right)$ is of form [2]:

$$
y-Y_{w_{A}}=\frac{Y_{w_{B}}-Y_{w_{A}}}{X_{w_{B}}-X_{w_{A}}}\left(x-X_{w_{A}}\right)
$$

Putting symbols of parameters of straight line (2), we receive:

$$
y=\alpha x+\beta
$$

where:

$$
\begin{gathered}
\alpha=\frac{Y_{w_{B}}-Y_{w_{A}}}{X_{w_{B}}-X_{w_{A}}} \\
\beta=Y_{w_{A}}-\frac{Y_{w_{B}}-Y_{w_{A}}}{X_{w_{B}}-X_{w_{A}}} X_{w_{A}}
\end{gathered}
$$

Assume, that point $C$ will be placed after transformation on line $A B$.

Coordinates of point $\mathrm{C}\left(\mathrm{X}_{p_{\mathrm{C}^{\prime}}} Y_{p_{\mathrm{C}}}\right)$ are determined in primary system (former cadastral map) but coordinates of point $\mathrm{A}\left(X_{w_{A}}, Y_{w_{A}}\right)$ i B $\left(X_{w_{B}}, Y_{w_{B}}\right)$ are determined in secondary system. So, one can write down:

$$
\begin{aligned}
& X_{w_{C}}=a X_{p_{C}}+b Y_{p_{C}}+c \\
& Y_{w_{C}}=d X_{p_{C}}+e Y_{p_{C}}+f
\end{aligned}
$$

Substituting (6) to formula (3) we get:

$$
a\left(\alpha X_{p_{C}}\right)+b\left(\alpha Y_{p_{C}}\right)+c \alpha-d X_{p_{C}}-e Y_{p_{c}}-f=-\beta
$$

It is conditional equation for point $C$.

\section{Parametric Model with Conditions on Unknowns}

Let coordinates of points determined in primary system fulfill set of equations (1), which in matrix notation, taking into account standard deviations $\delta$, takes a form: 


$$
\mathbf{X}_{\mathrm{w}}=\mathbf{X}_{\mathrm{p}} \times \mathbf{T}+\boldsymbol{\delta}
$$

which denotes that vector of coordinates in secondary system $\mathbf{X}_{\mathbf{w}}$ corresponds with estimated vector of coefficients of transformation $\mathbf{T}$ spanned on matrix $\mathbf{X}_{\mathrm{p}}$ determined on the basis of coordinates in primary system, together with random element in the form of vector $\boldsymbol{\delta}$.

On estimated coefficients of transformations, functional conditions of form (7) are put, which are in linear form; thus they can be recorded in the following matrix form:

$$
\mathbf{B} \times \mathbf{T}=\mathbf{W}
$$

Estimation of coefficients of transformation $\mathrm{T}$ is made by least square method (LSM), taking into account Lagrange function in the following form:

$$
\Psi=\left(\mathbf{X}_{\mathbf{w}}-\mathbf{X}_{\mathbf{p}} \times \mathbf{T}\right)^{\mathrm{T}} \times\left(\mathbf{X}_{\mathrm{w}}-\mathbf{X}_{\mathrm{p}} \times \mathbf{T}\right)+2 \mathbf{K}^{\mathrm{T}}(\mathbf{B} \times \mathbf{T}-\mathbf{W})=\min .
$$

Necessary conditions of minimum of this function are:

$$
\begin{aligned}
& \frac{\partial \Psi}{\partial \mathbf{T}}=2 \boldsymbol{X}_{\mathrm{p}}^{\mathrm{T}} \times \mathbf{X}_{\mathrm{p}} \cdot \mathbf{T}-2 \mathbf{X}_{\mathrm{p}}^{\mathrm{T}} \times \mathbf{X}_{\mathbf{w}}+2 \mathbf{B}^{\mathrm{T}} \times \mathbf{K}=\mathbf{0} \Rightarrow \\
& \Rightarrow \mathbf{X}_{\mathrm{p}}^{\mathrm{T}} \times \mathbf{X}_{\mathrm{p}} \cdot \mathbf{T}-\mathbf{X}_{\mathrm{p}}^{\mathrm{T}} \times \mathbf{X}_{\mathrm{w}}+\mathbf{B}^{\mathrm{T}} \times \mathbf{K}=\mathbf{0} \\
& \frac{\partial \Psi}{\partial \mathbf{K}}=2 \mathbf{B} \times \mathbf{T}-2 \mathbf{W}=\mathbf{0} \Rightarrow \mathbf{B} \times \mathbf{T}=\mathbf{W}
\end{aligned}
$$

Set of equations (13) and (14) one can record in block form:

$$
\left[\begin{array}{cc}
\mathbf{X}_{\mathrm{p}}^{\mathrm{T}} \times \mathbf{X}_{\mathrm{p}} & \mathbf{B}^{\mathrm{T}} \\
\mathbf{B} & \mathbf{0}
\end{array}\right] \cdot\left[\begin{array}{c}
\mathbf{T} \\
\mathbf{K}
\end{array}\right]=\left[\begin{array}{c}
\mathbf{X}_{\mathrm{p}}^{\mathrm{T}} \times \mathbf{X}_{\mathbf{w}} \\
\mathbf{W}
\end{array}\right]
$$

Solution of above set of equations can be done on the basis of block matrix inverse, being in formula (15) ahead of vector of unknowns, that is:

$$
\left[\begin{array}{cc}
\mathbf{X}_{\mathrm{p}}^{\mathrm{T}} \times \mathbf{X}_{\mathrm{p}} & \mathbf{B}^{\mathrm{T}} \\
\mathbf{B} & \mathbf{0}
\end{array}\right]^{-1}=\left[\begin{array}{cc}
\mathrm{C}_{1} & \mathrm{C}_{2} \\
\mathbf{C}_{3} & -\mathbf{C}_{4}
\end{array}\right]
$$

After solutions of set of four matrix equations, one can obtain the following formulas on elements of block matrix inverse:

$$
\mathbf{C}_{4}=\left(\mathbf{B} \times\left(\mathbf{X}_{\mathbf{p}}^{\mathrm{T}} \times \mathbf{X}_{\mathbf{p}}\right)^{-1} \times \mathbf{B}^{\mathrm{T}}\right)^{-1}
$$




$$
\begin{gathered}
\mathbf{C}_{3}=\mathbf{C}_{4} \times \mathbf{B} \times\left(\mathbf{X}_{\mathrm{p}}^{\mathrm{T}} \times \mathbf{X}_{\mathrm{p}}\right)^{-1} \\
\mathbf{C}_{2}=\left(\mathbf{X}_{\mathrm{p}}^{\mathrm{T}} \times \mathbf{X}_{\mathrm{p}}\right)^{-1} \times \mathbf{B}^{\mathrm{T}} \times \mathbf{C}_{4}=\mathbf{C}_{3}^{\mathrm{T}} \\
\mathbf{C}_{1}=\left(\mathbf{X}_{\mathrm{p}}^{\mathrm{T}} \times \mathbf{X}_{\mathrm{p}}\right)^{-1}-\left(\mathbf{X}_{\mathrm{p}}^{\mathrm{T}} \times \mathbf{X}_{\mathrm{p}}\right)^{-1} \times \mathbf{B}^{\mathrm{T}} \times \mathbf{C}_{3}
\end{gathered}
$$

After taking into account matrices (15)-(18) in formula (13), estimators of vectors of coefficients of transformations and vector of Lagrange coefficients, are expressed by following formulas:

$$
\begin{aligned}
& \hat{\mathbf{T}}=\mathbf{C}_{1} \times \mathbf{X}_{\mathrm{p}}^{\mathrm{T}} \times \mathbf{X}_{\mathbf{w}}+\mathbf{C}_{2} \times \mathbf{W} \\
& \hat{\mathbf{K}}=\mathbf{C}_{3} \times \mathbf{X}_{\mathbf{p}}^{\mathrm{T}} \times \mathbf{X}_{\mathbf{w}}+\mathbf{C}_{4} \times \mathbf{W}
\end{aligned}
$$

Value of function (10) one can express by estimators of coefficients of Lagrange function, that is according to formula:

$$
\Psi=\mathbf{X}_{\mathrm{w}}^{\mathbf{T}} \times \mathbf{X}_{\mathrm{w}}-\hat{\mathbf{T}}^{\mathbf{T}} \times \mathbf{X}_{\mathrm{p}}^{\mathbf{T}} \times \mathbf{X}_{\mathrm{w}}-\hat{\mathbf{K}}^{\mathbf{T}} \times \mathbf{W}
$$

After taking into account (17), unbiased estimator of variation of random element, expresses formula:

whereby:

$$
\hat{\sigma}^{2}=\frac{\psi}{n-k-w}
$$

$n$ - number of all considered equations for coordinates of primary and secondary systems,

$k$ - denotes number of estimated coefficients of transformation $(k=6)$, but $w=R(\mathbf{B})$ is a number of independent conditional equations.

Matrix of co-variance of estimated vector $\hat{\mathbf{T}}$ one can determine according to following formula:

$$
\operatorname{Cov}(\hat{\mathbf{T}})=\hat{\sigma}^{2} \times \mathbf{C}_{1}
$$

Elements being on diagonal of matrix (23) are variances of individual coefficient of transformation, estimated by model (19).

It is worth adding at this place, that in case of different reliability of location of individual control points, it is possible to put weight matrix to set of equations expressed by formula (13). This would make possible to complete matrix $\mathbf{B}$ with additional conditions for boundary lines, which endpoints changed their location but directions of these lines remained the same. For points representing such line, one should take very small weights. 


\section{Computation of Coefficients of Transformation with Conditions on Unknowns}

In order to verify accepted assumptions, coefficients of transformation, for case shown on Figure 2, have been computed.

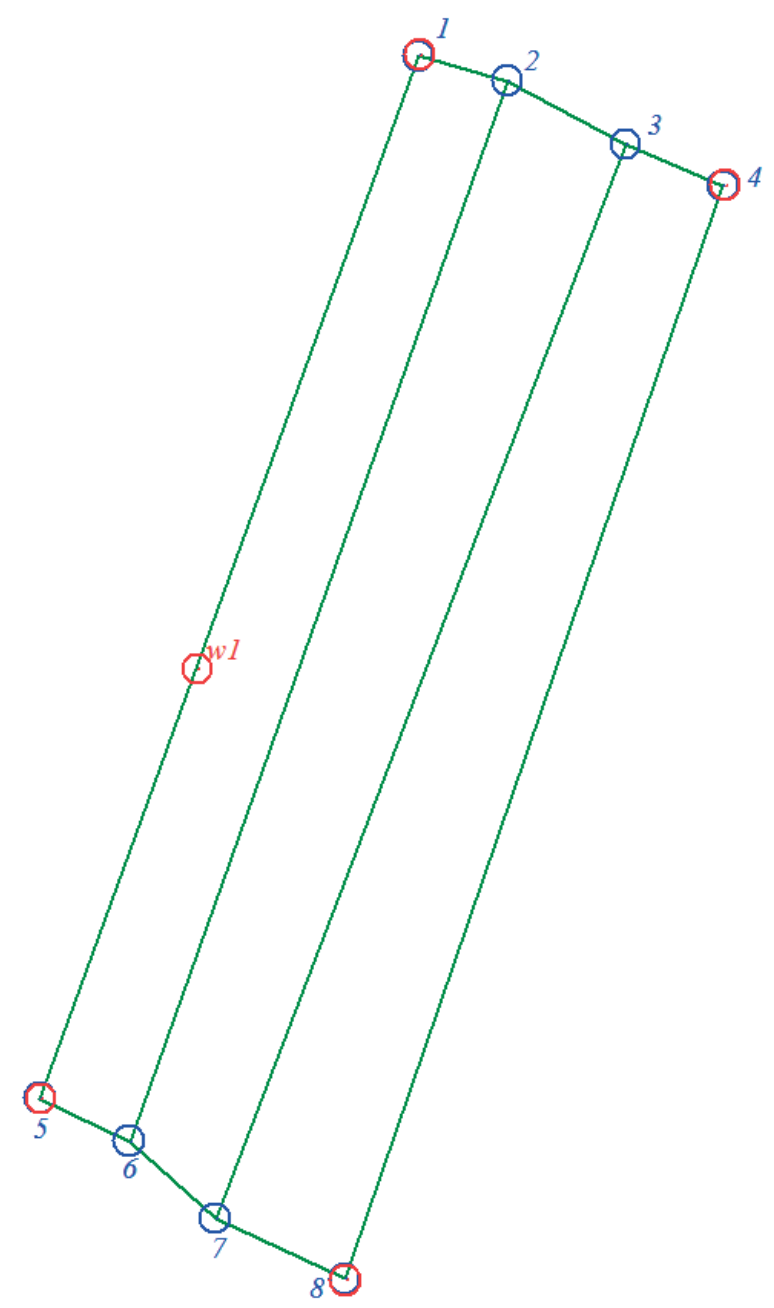

Fig. 2. Example of transformation with additional conditions on unknowns

In presented above example, only points $1,4,5$ and 8 have coordinates in primary and secondary systems. Points 2, 3, 6 and 7 have coordinates only in secondary system. Yet, it is known that point w1, which coordinates have been determined in primary system, has to be placed after transformation on line formed by points 1 and 5 . 
Coordinates of control points 1, 4, 5 and 8 in primary and secondary system, and coordinates of point w1 in primary system shows Table 1.

Table 1. List of points coordinates

\begin{tabular}{|c|c|c|c|c||}
\hline \multirow{2}{*}{ Point number } & $X_{p}[\mathrm{~m}]$ & $Y_{p}[\mathrm{~m}]$ & $X_{w}[\mathrm{~m}]$ & $Y_{w}[\mathrm{~m}]$ \\
\hline \hline 1 & 4793.72 & 3934.01 & 4793.44 & 3933.70 \\
\hline 4 & 4762.66 & 4006.82 & 4762.57 & 4006.21 \\
\hline 5 & 4545.05 & 3843.78 & 4545.20 & 3843.59 \\
\hline w1 & 4501.80 & 3916.38 & 4502.21 & 3916.38 \\
\hline
\end{tabular}

Matrix $\mathbf{X}_{\mathrm{p}^{\prime}}$ containing only equations made for control points, and matrix $\mathbf{X}_{\mathbf{w}}$ for such case will be as follows:

$$
\begin{gathered}
\mathbf{X}_{\mathrm{p}}:=\left[\begin{array}{cccccc}
x_{1} & y_{1} & 1 & 0 & 0 & 0 \\
0 & 0 & 0 & x_{1} & y_{1} & 1 \\
x_{4} & y_{4} & 1 & 0 & 0 & 0 \\
0 & 0 & 0 & x_{4} & y_{4} & 1 \\
x_{5} & y_{5} & 1 & 0 & 0 & 0 \\
0 & 0 & 0 & x_{5} & y_{5} & 1 \\
x_{8} & y_{8} & 1 & 0 & 0 & 0 \\
0 & 0 & 0 & x_{8} & y_{8} & 1
\end{array}\right] \\
\mathbf{X}_{\mathrm{p}}=\left[\begin{array}{ccccccc}
4.79372 \cdot 10^{3} & 3.93401 \cdot 10^{3} & 1 & & 0 & \\
0 & 0 & 0 & 4.79372 \cdot 10^{3} & 3.93401 \cdot 10^{3} & 1 \\
4.76266 \cdot 10^{3} & 4.00682 \cdot 10^{3} & 1 & 0 & 0 & 0 \\
0 & 0 & 0 & 4.76266 \cdot 10^{3} & 4.00682 \cdot 10^{3} & 1 \\
4.54505 \cdot 10^{3} & 3.84378 \cdot 10^{3} & 1 & 0 & 0 & 0 \\
0 & 0 & 0 & 4.54505 \cdot 10^{3} & 3.84378 \cdot 10^{3} & 1 \\
4.5018 \cdot 10^{3} & 3.91638 \cdot 10^{3} & 1 & 0 & 0 & 0 \\
0 & 0 & 0 & 4.5018 \cdot 10^{3} & 3.91638 \cdot 10^{3} & 1
\end{array}\right]
\end{gathered}
$$




$$
\mathbf{X}_{\mathbf{w}}:=\left[\begin{array}{c}
X_{1} \\
Y_{1} \\
X_{4} \\
Y_{4} \\
X_{5} \\
Y_{5} \\
X_{8} \\
Y_{8}
\end{array}\right] \quad \mathbf{X}_{\mathbf{w}}=\left[\begin{array}{c}
4.79344 \cdot 10^{3} \\
3.9337 \cdot 10^{3} \\
4.76257 \cdot 10^{3} \\
4.00621 \cdot 10^{3} \\
4.5452 \cdot 10^{3} \\
3.84359 \cdot 10^{3} \\
4.50221 \cdot 10^{3} \\
3.91638 \cdot 10^{3}
\end{array}\right]
$$

In turn, matrix $\mathbf{B}$ with conditions and matrix $\mathbf{W}$ will have forms:

$$
\mathbf{B}:=[\alpha 1 \cdot x w 1 \quad \alpha 1 \cdot y w 1 \quad-x w 1 \quad-y w 1 \quad-1]
$$

$\mathbf{B}=\left[\begin{array}{lllll}1.6869526 \cdot 10^{3} & 1.4088073 \cdot 10^{3} & 0.3629955 \cdot 10^{3} & -4.64731 \cdot 10^{3} & -3.88106 \cdot 10^{3}\end{array}\right]$

$$
\begin{gathered}
\mathbf{W}:=[-\beta 1] \\
\mathbf{W}=\left[-2.1937029 \cdot 10^{3}\right]
\end{gathered}
$$

Considering formulas (15)-(19), we result coefficients of transformations regarding condition for point $\mathrm{w} 1$. Values of coefficient shows matrix $\mathrm{T}$ :

$$
\mathbf{T}=\left[\begin{array}{r}
0.9977387 \\
0.0011081 \\
6.2451749 \\
-0.0016214 \\
1.000801 \\
4.0352498
\end{array}\right]
$$

It is worth remarking that in traditional approach, without taking into account condition for point $\mathrm{w} 1$, these coefficients computed on the basis of least square method from equation:

$$
\mathbf{X}=\left(\mathbf{X}_{\mathrm{p}}^{\mathrm{T}} \cdot \mathbf{X}_{\mathrm{p}}\right)^{-1} \mathbf{X}_{\mathrm{p}}^{\mathrm{T}} \mathbf{X}_{\mathbf{w}}
$$


will be as follows:

$$
\mathbf{X}=\left[\begin{array}{c}
0.9975225 \\
0.0018352 \\
4.3665144 \\
-0.0010256 \\
0.998798 \\
9.2106872
\end{array}\right]
$$

After taking into account coefficients of transformation, shown in matrix $\mathbf{T}$ distance between point $\mathrm{w} 1$ and line $1-5$ is $\mathrm{d}=-0.00004 \mathrm{~mm}$. In case of applying coefficients from matrix $\mathbf{X}$ this distance is $\mathrm{d}^{\prime}=181.2 \mathrm{~mm}$

Standard deviations of transformation coefficients, computed on the basis of formula (23), together with values of these coefficients, have been shown in Table 2. In column 4 of this table standard deviations of coefficients of transformation when additional conditions were not used, have been written. Values put in column 4 have been computed on the basis of formula given in [1].

$$
\operatorname{Cov}(\mathbf{X})=\sigma^{2}\left(\mathbf{X}_{\mathbf{p}}^{\mathrm{T}} \times \mathbf{X}_{\mathbf{p}}\right)^{-1}
$$

where:

$$
\sigma^{2}=\frac{\mathbf{X}_{\mathrm{w}}^{\mathrm{T}} \mathbf{X}_{\mathrm{w}}-\mathbf{X}^{\mathrm{T}} \mathbf{X}_{\mathrm{p}} \mathbf{X}_{\mathrm{w}}}{n-u}
$$

whereby $n=8$ (number of equations) but $u=6$ (number of unknowns).

Table 2. Values of coefficients of transformation together with their standard deviations

\begin{tabular}{|c|c|c|c||}
\hline $\begin{array}{c}\text { Coefficient of } \\
\text { transformation }\end{array}$ & $\begin{array}{c}\text { Value of coefficient of } \\
\text { transformation with } \\
\text { applying conditions }\end{array}$ & $\begin{array}{c}\text { Standard deviation } \\
\text { of coefficient of } \\
\text { transformation with } \\
\text { applying conditions }\end{array}$ & $\begin{array}{c}\text { Standard deviation } \\
\text { of coefficient of } \\
\text { transformation without } \\
\text { applying conditions }\end{array}$ \\
\hline$a$ & 0.9977387 & 0.0018253 & 0.0008958 \\
\hline$b$ & 0.0011081 & 0.0039839 & 0.0019894 \\
\hline$c$ & 6.2451749 & 11.773469 & 5.8381750 \\
\hline$d$ & -0.0016214 & 0.0016587 & 0.0008958 \\
\hline$e$ & 1.0008010 & 0.0030514 & 0.0019894 \\
\hline$f$ & 4.0352498 & 9.7373312 & 5.8381750 \\
\hline
\end{tabular}


Transformation error one can determine by computing sum of square differences between recorded value of coordinates of control points in secondary system and values obtained by application of estimated coefficients of transformation. One can present it in discussed problem by following formula:

$$
\frac{\left(\mathbf{X}_{\mathbf{w}}-\mathbf{X}_{\mathbf{p}} \cdot \mathbf{T}\right)^{\mathrm{T}} \cdot\left(\mathbf{X}_{\mathbf{w}}-\mathbf{X}_{\mathbf{p}} \times \mathbf{T}\right)}{n-k}
$$

In case of using additional condition this value equals $0.061 \mathrm{~m}$. In case when transformation error is less than in the first case and equals $0.029 \mathrm{~m}$.

\section{Conclusions}

Transformation of cadastral maps, especially cadastral maps of lands of former Austrian annexation is a difficult process, needing much experience. Taking into account rules of preparing these maps, deformations occurring on them are not uniform. This process is additionally complicated because boundary points were not fixed and that graphic method of making these maps was used. By applying these maps during such surveying-legal processes as delimitation or real estate legal status regulation, it is necessary to select correct located control points in suitable amount. It results from character of these works and necessity of application non-conformal transformation, as well. Lack of suitable amount of control points, occurring very often, can be balanced by additional conditions taken on boundary lines. It can be especially important for elongated parcels, located on agricultural and forest lands.

Addition to transformation such conditions cause:

- obtaining better consistency in boundary course with small increasing transformation error,

- make transformation possible in case of lack necessary amount of control points or when control points arrangement is incorrect,

- improving reliability of obtained results.

It proves conclusions got in [2]. Nevertheless, presented in the article method, gives precise results, and not as it is in quoted article - approximate results.

It is also possible in presented procedure to add conditions for boundary line, when their endpoints changed their location. Such approach needs only adding weight matrix and applying small weights for points which location have been changed (for example opoints located by roads).

\section{References}

[1] Czaja J.: Modele statystyczne w informacji o terenie. Wydawnictwa AGH, Kraków 1997. 
[2] Hanus P.: Wykorzystanie transformacji z warunkami w procesie ustalenia granic. Geomatics and Environmental Engineering, vol. 1, no. 3, 2007, pp. 49-60.

[3] Hanus P., Szczutko T.: Opinia wykonana na potrzeby Sadu Rejonowego w Żywcu w sprawie o rozgraniczenie nieruchomości - obręb Zarzecze. Kraków, Żywiec 2005.

[4] Kubowicz H.: Możliwość wykorzystania map katastru austriackiego przy modernizacji ewwidencji gruntów i budynków. Geodezja, Kartografia i Fotogrametria, 63, Min. Oświaty i Nauki Ukrainy, Wyd. Politechniki Lwowskiej, Lwów 2003.

[5] Noga K., Schilbach J.: Badania nad możlizwościa wykorzystania map byłego katastru austriackiego do prac scaleniowych. Zeszyty Naukowe AR w Krakowie, nr 4, 1973.

[6] Rozporzadzenie Ministra Rozwoju Regionalnego i Budownictwa z 29 marca 2001 w sprawie ewwidencji gruntów i budynków. Dz. U. z 2001 r. Nr 38, poz. 454.

[7] Sitek Z.: Fotogrametria ogólna i inżynieryjna. Państwowe Przedsiębiorstwo Wydawnictw Kartograficznych im. Eugeniusza Homera, Warszawa - Wrocław 1991.

[8] Taszakowski J.: Ocena przydatności map byłego katastru austriackiego dla regulacji stanu prawnego nieruchomości w potudniowej Polsce. Infrastruktura i Ekologia Terenów Wiejskich, nr 4, 2011, pp. 7-19. 